\title{
The Validity Of Notary's Agreement Which Is Signed Outside The Notary's Office
}

\begin{abstract}
Dina Harindra Trisnani ${ }^{1}$ and Umar Ma'ruf ${ }^{2}$
Abstract. Article 19 paragraph (3), Article 3 paragraph 8 and Article 3 number 15 in Code of Ethics of Notary is a regulation governing the signing of notarial agreement at Notary's office. However, in practice, there is a case of signing the Agreement not in the Notary's Office. The problem formulated is how the validity of notarial agreements signed not in the Notary's office and how the supervision of Notary in the signing of notarial agreement so that it is in accordance with notarial agreement. To answer the above problems, the author used normative research methods and a research approach; legal approach, conceptual approach, case approach and practical approach. Methods of data collection research used literature study method and the data were analyzed by qualitative analysis techniques and used deductive conclusions. According to the research, the validity of Notarial Agreement signed not at the Notary office has the following criteria; firstly, notarial agreements that are signed are not in the Notary's office but are still in the Notary's territory, the agreements are valid as long as there are special reasons. Secondly, notarial agreements signed not in the Notary office and not in positions of Notary's territory but still in the Notary's office area remain valid as long as it is done not sequentially and accompanied by specific reasons. Third, the Notary who signed the agreement not in his Notary's office and outside the territory of Notary Office, the agreement becomes invalid. Notary Supervision in signing of Notary Agreement pursuant to Notary Law and Notary Code of Indonesia is done by Supervisory Notary Board. Supervision by the Notary Board is done through preventive and curative activity including development activities. Supervision by Notary Board is done in two ways, namely: active supervision which checks Notary protocol and passive supervision which checks Notary statements.
\end{abstract}

Keywords: Notary; Signing Agreement; Unnotary Office.

\section{Introduction}

Notary is a profession in the field of law, especially in providing agreement making services. A Agreement made by a Notary can be the legal basis of a person's property, rights and duties ${ }^{3}$. The position of a Notary is regulated by Act No. 30 Of 2004 regarding the Notary's Office, as amended by Act No. 2 Of 2014 regarding Amendment to Act No. 30 Of 2004 regarding Notary Position, (hereinafter abbreviated to the Notary Position Law/UUJN). Besides, it is stipulated in the Notary Position Law, the implementation of Notary Position is also regulated in the code of ethics of Indonesian Notaries Association (INI). The authentic agreements are regulated in Article 1868 of the Civil Code $^{4}$, the authentic agreements are made in a form prescribed by law and

\footnotetext{
${ }^{1}$ Master of Notary's Student Sultan Agung Islamic University (UNISSULA) Semarang email dinaharindra@gmail.com

${ }^{2}$ Lecturer of Faculty of Law UNISSULA

${ }^{3}$ Abdul Ghofur Anshori 2009 Lembaga Kenotariatan Indonesia Perspektif Hukum dan Etika Yogyakarta UII Press p. 25

${ }^{4}$ Article 1 no. 1 and Article 1 no. 7 the Act of Notary
} 
made by or in the presence of authorized public authorities. Some of the authorized public officials are such as Auction officials, Land Agreement Officials, Notaries and other public officials. Notary is a public official authorized to make a agreement, so that the agreement made by or in the presence of a Notary is an authentic agreement ${ }^{5}$. If a person commits a legal act and he/she wishes to obtain a guarantee of legal certainty that provides legal protection, then he/she must make an authentic agreement.

The signature is usually located in the end of the agreement. On the basic rules or principles of the British common law which apply to the standard agreements in order for excitation clauses (and other aggravating clauses) contained in a written agreement signed by the parties to bind the parties concerned. In such case, it is not important whether the signatory of the agreement has read the agreement or understands the contents of the agreement. It is enough for the other party that the inclusion of the signature is evidence of the attachment of the undersigned. ${ }^{6}$ By looking at the above information, the signature is clearly an important thing that must exist in a agreement. The provisions relating to Article 19 Paragraph (3) of the Notary Office Law are in the Notary Code of Ethics in the provisions of Article 3 number 8 of the Code of Notary which formulates that: "Establishing an office in a domicile and the office shall be the only office of the Notary concerned in the performance of day-to-day office duties."

In Article 3 number 15 of the Code of Notary which formulates that: 7 "Notary runs his/her duties in his/her office, except for certain reasons"

The signing of a Notary Agreement not in the Notary's office is still frequently occur, although the act is at risk of violating the rules of the Notary's office law as well as the Notary's code of ethics, but it is still done by certain Notaries.

Several cases of notarial agreement signing which is not in the Notary's office still happen, due to lack of supervision to the Notary. The supervision of Notary is very important, the supervision of Notary and the task of Notary can always be in accordance with the rule of law underlying authority and can be avoided from abuse of authority or trust given. 8

Based on the background description above, the problems analyzed in this research in detail can be formulated as follows: How is the validity of notarial agreement signed not at Notary's office? What is the supervision of Notary in signing the Notary Act so that it is in accordance with the Notary Office and Notary Code of Ethics contained in Indonesia?

\section{Research Methods}

\footnotetext{
5 R. Soegondo Notodisoerjo 2005 Hukum Notariat di Indonesia (Suatu Penjelasan) Jakarta Ghalia Indonesia p.89.

6 Sutan Remy Sjahdeini 2009 Kebebasan Berkontrak dan Perlindungan yang Seimbang Bagi Para Pihak Dalam Perjanjian Kredit Bank di Indonesia Jakarta PT Pustaka Utama Grafiti p. 89

7 Article 3 no. 15 Amandement of the Code of Notaries Ethic in Indonesia Banten 29-30 May 2015

${ }^{8}$ Habib Adjie 2015 Bernas-Bernas Pemikiran di Bidang Notaris dan PPAT Materiil Examination article 66 Act No. 30 of 2004 on Notarical Officer Master of Notary Faculty of Law Sriwijaya University Palembang p. 6
} 
The type of research in this study is normative legal research or legal research literature or doctrinal research. Normative legal research was used in this study to systematize, correct and clarify a rule of law applicable to a particular legal field by performing an analysis of authoritative texts covering primary and secondary legal materials. This research used the method of Legislative Approach, conceptual approach, case approach, and practical approach.

The technique of analysis of legal materials in this research was done by using qualitative analysis technique. This technique was used to analyze legal materials that have been obtained in the form of information. The description in the form of language and then associated with other data to get clarity to a truth or vice versa, so as to obtain a new picture or strengthen an existing picture. This technique is manifested by collecting legal materials and then interpreted by systematic interpretation, where systematic interpretation is used in this study in order to observe the relationship between one article and another in a law, in particular the articles of the Notary Law, The Code of Notary and the Civil Code.

\section{Discussion}

\subsection{Validity of Notary Agreement Signed Not at the Notary Office}

In the provision of Article 19 paragraph (3) of Act No. 02 Of 2014 on Amendment to Act No. 30 of 2004 concerning Notary Position (hereinafter abbreviated as Notary Law) formulates that: "Notary is not authorized sequentially by continuing to run position outside his place of residence."

In Article 19 Paragraph (3) of the Public Notary Law regulates the disability of Notary to run his office within the period of time mostly outside his domicile, in this case in the district or city. The provisions relating to Article 19 paragraph (3) of the Notary's Office Law are in the Notary Code of Ethics in the provisions of Article 3 point 8 of the Code of Notary which formulates that: "establishing an office in a domicile and the office shall be the only office Notary concerned in performing daily office duties."

In Article 3 number 15 of the Code of Notary which formulates that: "Notary runs his/her duties in his/her office, except for certain reasons"

By looking at the above provisions, the validity of the signing of notarial agreement not in the Notary's office can be divided into three forms, namely:

- Validity of Notarial Agreement Signed Not at the Notary's Office but Still in Notary's Territory.

On the signing of notarial agreement is not in the Notary's office but still in the territory of Notary, the notarial agreements are still valid, this is in accordance with the provisions of Article 18 paragraph (1) of the Notary Position Law, formulating the Notary has a domicile in the district or city, as well as in Article 3 paragraph 15 of the Notary Code of Ethics, which states that "Notary runs his/her duties in his/her office, except for certain reasons" ${ }^{\prime}$. It means, the Notary remains authorized to

\footnotetext{
${ }^{9}$ Prior to the amendment the formula is set forth in Article 3 point 14 which is: "Running Notary's office especially in the making reading and signing of deed is done in his office except for valid reasons
} 
exercise his/her position not in the Notary's office but still in his/her place of office for certain reasons, the signed agreement remains valid.

In the Laws and Regulations, the Regulation of the Minister of Law and Human Rights as well as in the Code of Ethics of Notary (Indonesian Notary Association), there is no explanation of how certain reasons are.

However, from the observation of researchers in practice, certain reasons are usually more due to the applicants/the parties who will make a agreement, not the reasons caused by the Notary. The reasons are usually in the form of urgent situations where the applicant/party cannot come directly to the Notary's office due to the urgency.

- Validity of Notary Agreement Signed Not at the Notary Office and Not in The Territory Notary's Position but Still in Notary Position Areas.

In signing of notarial agreement not in Notary office and not within the territory of Notary but still in the Area of Notary, the notarial agreements are still valid, this is in accordance with the provisions of Article 19 paragraph (3) Public Notary Law, which formulates Notary is not authorized in sequence by remaining in office outside his domicile ${ }^{10}$, as well as in Article 3 paragraph 15 of the Notary Code of Indonesia, which states that " Notary runs his/her duties in his/her office, except for certain reasons." It means, the Notary remains authorized to exercise his/her position not in his office, but he is still in the territory of Public Notary as long as it is done not in sequence and accompanied by certain reasons. The signing is still valid, but if it is done outside the Notary's territory, then the Notary has no authority. Not to do in sequence, it means to prevent the unhealthy competition among the notaries in place of the signing of the agreement takes place. If the Notary sign the agreement not in his office sequentially, it will make Notary become unauthorized and make the agreement becomes invalid.

- Validity of Notary Agreement signed not at the Notary Office in outside Official Position.

There is the signing of notarial agreement not in the Notary's office and outside the territory of Notary, then the agreement signed becomes invalid. Because, pursuant to the provision of Article 17 paragraph (1) letter a juncto Article 18 paragraph (2) of the Public Notary Law that a Notary is prohibited from performing a position outside his territory in which the position of Notary covers all provinces from his/her domicile.

Therefore, if this action is prohibited by law, then the agreement signed outside the territory of Notary's office becomes invalid, because the Notary has no authority and violates the law order.

The meaning of Article 17 Paragraph (1) Sub-Paragraph a of Article 18 Paragraph (2) of the Notary Law is that the Notary has the authority to perform his/her position in the territory of his/her office covering all areas in a province from his/her place of domicile, which means outside the territory of the office, Notary have no authority.

\footnotetext{
${ }_{10}$ Prior to the amendment the formula is set forth in Article 19 paragraph (2) which the formula is "Notary is not authorized to regularly perform a position outside his / her place of domicile.
} 
Since he has no authority, the execution of office especially in the matter of making, reading and signing the agreement outside the territory of Notary will affect the agreement made by or made in the presence of a Notary will become invalid and make the agreement only as an underhand agreement.

By looking at the three criteria above, it can be seen in the signing of notarial agreement applies the principle of gebeidsleer (the doctrine of scope) of Logemann, which states that the enactment of a norm in a legislation is based on four domains: 1) Scope of Personal Behavior (Personengebied); 2) Scope of Area Practices (Ruintegebied), 3) Time Scope (Tijdsgebied), and 4) Zaksgebied Scope of Behavior (Zaksgebied).

\subsection{Supervision Against Notary in the Signing of Notary Agreement in order to comply with the Law of Notary Position and Notary Code of Ethics in Indonesian Notaries Association (INI)}

Since the enactment of Act No. 30 Of 2004 regarding Notary Position as amended by Act No. 2 Of 2014 concerning Amendment to Act No. 30 Of 2004 Concerning Position of Notary Public, Notary supervision is no longer conducted by State Court in accordance with Notary working area concerned is located. There are two institutions authorized to conduct supervision to the Notary Public, the Supervisory Notary Board established by the minister in this case the Minister of Law and Human Rights of the Republic of Indonesia ${ }^{11}$. Notary Honorary Board is one of organization fittings, in this case is Indonesian Notary Association.

\subsubsection{Supervision by the Notary Honorary Board}

The main duties of the Notary Honorary Board is supervise the implementation of the Notary's code of ethics which has been determined by the organization, including obligations, restrictions and exceptions to be made by members of the organization. In performing its duties, the Notary Honorary Board may conduct an examination on the member of the organization that is allegedly committing a violation of the code of ethics and if the member is found guilty. The Notary Honorary Board is entitled to impose the sanction of the organization as stated in Article 6 of the Code of Ethics of the Indonesia Notary Bond Association, in the form of warning, dismissal, temporary dismissal and dismissal with disrespect from membership of the association. The authority of the Notary Honorary Board on the violation of the organizational ethical code whose effect is not directly related to the community or that there are no persons harmed by the violation of the code of ethics done by members of the organization. In other words, the authority of the Notary Honorary Board is internal to the organization. ${ }^{12}$

The Code of Ethics is set forth in Article 13 of the Regulation of Indonesia Notary Association as an order of Article 83 Paragraph (1) of the Notary Law of Position which is described in a code of ethics stipulated in the congress of Indonesian Notary Association, and must be obeyed by every member of the Association. From the code

11 Pasal 67 ayat (2) Undang-Undang Jabatan Notaris

12 Ibid p. 262 
of ethics, it can be chosen and decided which will include in the authority of the Notary Honorary Board or the authority of the Supervisory Board. Article 3 of the code of ethics of a Notary, regulates the obligation of a Notary, consisting of seventeen paragraphs authorized by the Notary Honorary Board, while the authority of the Supervisory Broad is contained in paragraphs 4, 8, 17, except sub $d$. These matters have been regulated in Article 4 paragraph (2) and Article 19 of the Public Notary Procedure Law, regarding the prohibition of Notary in carrying out their positions as regulated in Article 4 of Notary's code of ethics. ${ }^{13}$

\subsubsection{Supervision by the Notary Supervisory Board}

Since the enactment of the Notary Law, the institution which has the authority to supervise and inspect the Notary is the Minister, in this case is the authority of the Minister of Justice and Human Rights ${ }^{14}$. However, in its implementation, the Minister shall establish a Notary Supervisory Board. The Minister then delegates the authority supervision to MPN20 (Article 67 paragraph (2) of Notary Position Law). Based on Article 68 of the Notary Position Law, the Notary Supervisory Board consists of: ${ }^{15}$

- Local Supervisory Board (hereinafter referred to as MPD), established and domiciled in the Regency or City.

- Regional Supervisory Board (hereinafter referred to as MPW), established and domiciled in the provincial capital.

- The Central Supervisory Board (hereinafter referred to as MPP), established and domiciled in the State Capital.

By looking at the above points, the institution who supervises the notarial agreement signed nit in Notary's office is the Notary Supervisory Board.

In supervising the signing of Notarial Agreement, there are two ways that can be done by Supervisory Board. First is active supervision, it means the Broad directly check the Notary's Protocol, further, the final result of the Notary protocol is the Official Report. This official report then is submitted to the Regional Supervisory Board, with a copy to the Notary concerned, Notary Organization and Central Supervisory Board. On the other hand, the passive Supervision is checking the public report. This report is issued by the Regional Supervisory Broad. This report contains the violation, oral and written sanction. the report shall be declared cancel and cannot be submitted again in the event that the complainant is absent after being summoned twice consecutively. Furthermore, the sanction is submitted to the Central Supervisory Board in the form of temporary termination or dismissal, and the decision shall be communicated to the Notary concerned with a copy to the Central Supervisory Board and the Notary Organization.

In the case of the decision being appealed to the Central Supervisory Board, the final result of the Notary's examination of the public report shall be a decision, whether the

\footnotetext{
${ }^{13}$ Ibid $\mathrm{p} 266$

${ }^{14}$ Habib Adjie Sanksi Perdata Dan Administratif Terhadap Notaris Sebagai Pejabat Publik Op.cit p. 128.

${ }^{15}$ Habib Adjie Majelis Pengawas Notaris Sebagai Pejabat Tata Usaha Negara Op.cit h. 5
} 
decision of the Notary is not guilty, the decision to impose a sanction of suspension, to the sanctions in the form of disrespect dismissal to Minister. ${ }^{16}$

\section{Conclusion}

Based on the analysis done by the author, it can be concluded that:

- The validity of notarial agreement signed not at the Notary office has the following criteria:

- Notary Agreement signed not in the Notary's office but still within the territory of the Public Notary is valid in case the signing process is done under certain circumstances or conditions of interception that the parties cannot possible to come directly to the Notary's office.

- Notary Agreement signed not at the Notary office but still within the territory of Public Notary is valid as long as it is done not in sequence. It is done to avoid unfair competition among Notaries and the signing process is done under certain circumstances or conditions of interception that the parties cannot possible to come directly to the Notary's office.

- Notary Agreement signed not in the Notary office and outside the territory of Public Notary is not valid, because the Notary does not have the authority to execute his/her position outside his/her territory. He/she cannot cover all provinces from his/her position, so that the agreement made will lose its authenticity and degraded to agreement under the hands.

- The supervision to the Public Notary in case of the signing of Notary Agreement in accordance with the Notary Office Law and the Notary's Code of Indonesia is performed by the Notary Supervisory Board. Supervision conducted by the Notary Supervisory Broad. The activities are preventive and curative including coaching activities. Supervision by the Notary Supervisory Board to the signature of Notary Agreement is done in two ways, namely:

- Monitoring is done actively by checking the Notary protocol which after examined then the monitoring results is given the examination report.

- Passive supervision is to check Notaries based on community reports.

The Notary Supervisory Broad is requested to ask notary to sign every signed document to be recorded in the form of a video or at least in the form of a photo during the signing of the agreement. The video or photo will be reported to the Supervisory Board along with a report on the signing of the agreement. This is done to distinguish the signing done in the notary office and not in the notary's office. The Supervisory Board of Notary must also be more proactive, if there is an indication of a notary violating the signing of the agreement, it should directly conduct an investigation without the need for a public report, and always hold regular meetings for notaries to discuss issues in the notary practice especially the signing of notarial agreement.

\footnotetext{
${ }^{16}$ Article 21-35 Ministry of Human Rights of Indonesia No..02.PR.08.10 of 2004 on procedure of taking the officer.
} 


\section{References}

[1] Abdul Ghofur Anshori 2009 Lembaga Kenotariatan Indonesia Perspektif Hukum dan Etika Yogyakarta UII Press.

[2] R. Soegondo Notodisoerjo 2005 Hukum Notariat di Indonesia (Suatu Penjelasan) Jakarta Ghalia Indonesia.

[3] Sutan Remy Sjahdeini 2009 Kebebasan Berkontrak dan Perlindungan yang Seimbang Bagi Para Pihak Dalam Perjanjian Kredit Bank di Indonesia Jakarta PT Pustaka Utama Grafiti.

[4] Amandement of the Code of Notaries Ethic

[5] Habib Adjie 2015 Bernas-Bernas Pemikiran di Bidang Notaris dan PPAT Materiil Examination article 66 Act No. 30 of 2004 on Notarical Officer Master of Notary Faculty of Law Sriwijaya University Palembang.

[6] Undang-Undang Jabatan Notaris 